\title{
Role of bone marrow derived pluripotent stem cells in peripheral nerve repair in adult rats: A morphometric evaluation
}

\author{
Nilesh S. Kurwale ${ }^{1}$, Vaishali Suri², Arati Srivastava², Ashish Suri ${ }^{1}$, Sujata Mohanti ${ }^{3}$, Pradeep Yadav ${ }^{4}$, Meher C. Sharma ${ }^{2}$, \\ Chitra Sarkar ${ }^{2}$ \\ Departments of Neurosurgery ${ }^{1}$ Pathology ${ }^{2}$, Stem Cell Facility ${ }^{3}$ and Central Animal Facility ${ }^{4}$, All India Institute of Medical Sciences, New Delhi, \\ India
}

\begin{abstract}
Objectives: Semi-quantitative and quantitative assessment of the effect of bone marrow-derived mononuclear cells (BM-MNC) on early and late phase of nerve regeneration in rat sciatic nerve model. Materials and Methods: Sciatic nerve transection and repair was performed in 50 inbred female Wistar albino rats divided equally in two groups. In the test group the gap was filled with BM-MNCs obtained from the two male rats and fibrin sealant, while in the control group only fibrin sealant was used. Sciatic nerve was harvested at 15 days and at 60 days interval. Parameters of regeneration were assessed at anastomosis (G), intermediate distal (C), and distal site (A). Semi-quantitative (histopathological) and quantitative (morphometric) parameters were analyzed. Results: At 15 days there was a statistically significant difference found in mean axon diameter, mean nerve thickness and myelin thickness at the repair site $(P<0.05)$. However, in the distal areas, the axons were sparse and myelin rings were very thin in both the groups. At 60 days, the difference in above-mentioned parameters was statistically significant at the distal most sites. FISH assay confirmed the presence of Y chromosome, confirming the presence of BM-MNCs from the male rats. Conclusions: Transplanting $\mathrm{BM}-\mathrm{MNC}_{\mathrm{S}}$ at the site of peripheral nerve injury leads to significantly better recovery. These differences were evident at the repair site and at the intermediate distal site at 15 days and at the distal most sites at 6o days. With practically no ethical issue regarding their isolation and application, they can be easily used for clinical trials.
\end{abstract}

Key words: Bone marrow-derived mononuclear cells, nerve repair, rats sciatic nerve model, stem cells

\section{Introduction}

Axonal regeneration in injured peripheral nerve is slow process and associated with poor outcomes if nerves are not restored surgically. The growth of regenerating axons is supported by local Schwann cells by providing the necessary environment rich in growth factors, neurotrophins, cell adhesion molecules, and transcriptors. $^{[1,2]}$ Thus, Schwann cells acts as a crucial component of nerve regeneration.

\begin{tabular}{|l|l|}
\hline \multicolumn{2}{|c|}{ Access this article online } \\
\hline Quick Response Code: & Website: \\
\hline & www.ruralneuropractice.com \\
\cline { 2 - 2 } & \\
\hline & DOI: \\
\hline
\end{tabular}

Over the years Schwann cell remained the main focus among researchers. Initial attempts were to deliver the Schwann cells directly to the injury site for improving the myelination and regeneration. ${ }^{[3,4]}$ However, initial enthusiasm was faded by the practical difficulty of harvesting Schwann cells by invasive nerve biopsies and long durations of in vitro cultures to attain the optimal delivery concentrations. Various embroyonic cell lines were used subsequently to derive Schwann cells. However, technical difficulties in isolation of these cell lines limited their use to research laboratories. ${ }^{[5,6]}$

Bone marrow-derived stem cells attracted many researchers because of their ease of harvesting, processing, storage and transportation. These bone marrow stem cells are known to differentiate into Schwann cells in the milieu rich in growth factors and neurotrophins present at the site of nerve injury and

Address for correspondence:

Dr. Vaishali Suri, Department of Pathology, All India Institute of Medical Sciences, Room No 1089, Teaching Block First Floor, Ansari Nagar, New Delhi - 110 029, India. E-mail: surivaishali@yahoo.co.in 
active regeneration. ${ }^{[7,8]}$ Few studies are available in the literature documenting the role of bone marrow-derived stem cells in motor and sensory recovery in rat peripheral nerve regeneration model, while few papers focused on histopathological markers of nerve regeneration. ${ }^{[9-12]}$

In previous studies by the same authors, fibrin glue and bone marrow-derived mononuclear cells (BM-MNC) were shown to have a beneficial effect in the peripheral nerve regeneration in rats. ${ }^{[13,14]}$ To substantiate the observations of the previous studies, we performed detailed quantitative (morphometric) evaluation of nerve regeneration. We tried to analyze the efficacy of BM-MNCs in peripheral nerve regeneration and also tried to explore the differential effects if any, on early and delayed phases of nerve regeneration.

\section{Materials and Methods}

\section{Animals (number and grouping)}

Fifty adult female inbred Wistar albino rats, weighing between 250 and 300 gm were equally divided in two groups: Test (group 1) and control (group 2). Bone marrow cells were harvested from two male rats. Male donors were used to demonstrate the presence of $Y$ chromosome in nucleated cells in transplanted nerves. Permission of the experiment was taken from the Ethics Committee of All India Institute of Medical Sciences, New Delhi. The study was divided into two phases having study periods 15 days and 60 days, respectively [Table 1].

\section{Preparation of bone marrow mononuclear cells (BM-MNCs)}

Bone marrow was aspirated from femur and tibia using disposable needle from male Wistar albino rats being sacrificed for other purposes. Bone marrow from 2 rats of same litter was pooled to get optimum number of mononuclear cells. It was collected in heparinized syringes. Mononuclear cells (MNC) were separated by the "Ficoll density gradient separation method."[15] Viability of the cells was tested using trypan blue stain. Cells were counted in the Neubaur chamber under a microscope to assess the number. 4-8 million MNCs were suspended in $1 \mathrm{ml}$ of normal saline and used for transplantation within 4 hours of preparation.

Table 1: Details of the study design with numbers of rat designated to each group

\begin{tabular}{|c|c|c|c|c|c|c|c|}
\hline \multirow[t]{2}{*}{ Group } & \multirow{2}{*}{$\begin{array}{l}\text { Study } \\
\text { period } \\
\text { (days) }\end{array}$} & \multicolumn{2}{|c|}{$\begin{array}{c}\text { Morphometric } \\
\text { evaluation }\end{array}$} & \multicolumn{2}{|c|}{$\begin{array}{l}\text { Longitudinal } \\
\text { sections }\end{array}$} & \multicolumn{2}{|c|}{$\begin{array}{c}\text { Transverse } \\
\text { section }\end{array}$} \\
\hline & & Test & Control & Test & Control & Test & Control \\
\hline 1 & 15 & 5 & 5 & 5 & 5 & 5 & 5 \\
\hline 2 & 60 & 5 & 5 & 5 & 5 & - & - \\
\hline
\end{tabular}

Transplantation of bone marrow mononuclear cells (BM-MNCs)

The nerve injury repair model in rats was standardized in the previous study. ${ }^{[13]}$ In each phase, the female rats were anesthetized with intraperitoneal sodium pentothal in a dose of $40 \mathrm{mg} / \mathrm{kg}$. Dorsal aspect of right hip and thigh was shaved and prepared. The sciatic nerve exposed, dissected and transected under an operating microscope. In the test group, cut ends of the nerve were approximated, with two epineural microsutures (10-0 monofilament nylon 2 placed at $180^{\circ}$ under 25 times magnification) and the gap was filled with rat bone marrow-derived mononuclear precursor cells (2-4 million MNC suspended in $0.5 \mathrm{ml}$ normal saline). The approximated nerve ends were then covered with fibrin glue (Tisseel; Baxter Healthcare Corp., Deerfield, IL, USA).

In the control group, the transected nerve ends were repaired with two epineural microsutures using 10-0 monofilament nylon and fibrin sealant only. A single surgeon performed all the nerve anastomoses. The rats were allowed to recover from anesthesia and were then kept in the animal care facility of the institute. Rats were reared by trained animal care workers and regularly followed. Subsequently they were taken up for nerve harvesting as per schedule.

\section{Nerve harvesting and processing}

On days 15 and 60, the right sciatic nerve was re-explored and approximately $12 \mathrm{~mm}$ of a nerve centered on the anastomosis site was harvested. Distal end of the harvested nerve was labeled for reference. The nerve was fixed in 3\% gluteraldehyde and divided into five parts [Figure 1] and sections were taken from each segment. Thin and semi-thin sections were taken for semi-quantitative (transverse sections) and morphometric analysis respectively from the paraffin-embedded blocks of the nerve. Only paraffin-embedded nerves were used for longitudinal sections of the nerve.

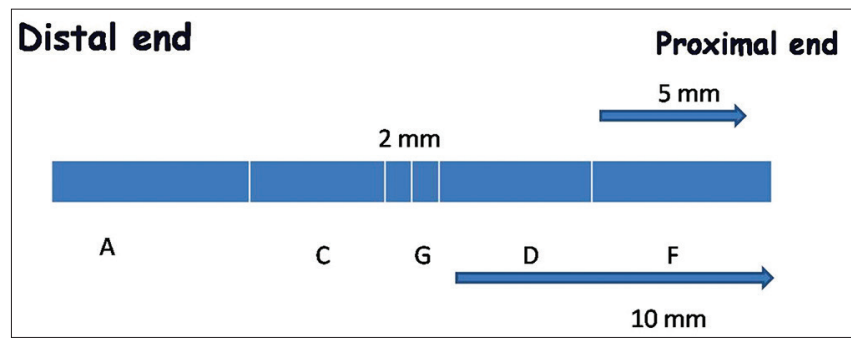

Figure 1: The schematic diagram of divisions of the harvested nerve for morphometric analysis. ' $G$ ' is the anastomosis site. ' $A$ ' is the distal most site while ' $F$ ' is the proximal site. Intermediate sites ' $C$ ' and ' $D$ ' respectively were also defined. Sections were taken from these sites in each specimen for analysis 
Brief procedure for nerve processing for morphometry The segments fixed in 3\% gluteraldehyde were post fixed in $1 \%$ osmium tetroxide at $4^{\circ} \mathrm{C}$ for 2 hours and then washed with phosphate buffer and then double distilled water. It was followed by routine dehydration (using increasing strength of ethyl alcohol at $4^{\circ} \mathrm{C}$ ); clearing in propylene oxide with 2 changes of 30 minutes each; impregnation and embedding in epoxy resin; polymerization in an oven at $50^{\circ} \mathrm{C}$ for 24 hours and then $60^{\circ} \mathrm{C}$ for 48 hours. The tissue pieces were oriented so as to yield transverse sections. One micron semi-thin sections, cut and stained with toluidine blue were analyzed.

\section{Semi-quantitative analysis}

The nerve segments obtained were processed for routine paraffin embedded blocks, so as to obtain transverse sections and longitudinal sections. Routine hematoxylin and eosin staining was done to look for nerve architecture and general histological details including inflammatory changes and inflammatory infiltrates. Special stains like Masson's trichrome stain (fibrosis and myelination), Luxol fast blue stain by modified Kluver's method (myelination) and Loyez stain (myelination) were used accordingly.

\section{Immunohistochemistry (IHC)}

IHC by streptavidin biotin labeling technique was performed (with diaminobenzidine as a chromogen), using positive and negative controls. The antibodies used were Neurofilament protein (NFP) (Dako; 1:100 dilution), Myelin Basic Protein (Neomarker; 1:100 dilution), CD34 (Dako; 1:200 dilution), S100 (Neomarker; 1:200 dilution), and Leukocyte common antigen (LCA) (Dako; 1:100 dilution). In addition GAP-43 expression (abm; 1:25 dilution) was also observed on longitudinal sections for assessment of regenerating axons.

Semi-quantitative analysis was performed by three observers (VS, CS and MCS) blinded to the specimen details. The number of axons and myelinated fibers were counted in three fields at $400 \times$ and expressed as percentage of cross-sectional area and numbers of specimens with thick or thin myelin rings were counted at each site [Table 2].

\section{Morphometric analysis}

Semi-thin sections $(1 \mu \mathrm{m})$ were taken from the tissue and processed for morphometric analysis. The sections were visualized under oil immersion and images from three different areas, studied with image-pro express 0.6 software with at least 200 observations for each parameter at every section taken. Morphometric analysis was performed by measuring number of myelinated axons, axon diameter, myelin sheath thickness and diameter of myelinated fibers.
Fluorescence in-situ hybridization (FISH) assay

Mononuclear cells of male rats were implanted at the right sciatic nerve injury site of female rats so the interphase FISH assay was performed for the $Y$ chromosome paint of mouse.

\section{Statistical analysis}

Data was arranged using Microsoft excel and analyzed using statistical software (Stata 9, Statacorp LP). Morphometric data was analyzed using cluster analysis. Appropriate tests of statistical significance were applied with level of significance chosen at $\leq 0.05$.

\section{Results}

There was no separation of the stumps or adhesion to the surrounding structures in any of the repaired nerves when seen under the operating microscope at the time of harvesting nerve grafts.

\section{Semi-Quantitative Analysis}

\section{Transverse sections}

\section{Axonal regeneration}

At 15 days both in test and control groups only partial recovery was noticed. In both the groups axons were relatively smaller, haphazardly arranged and sparsely placed [Figure 2]. Difference was observed at the repair site in number and percentage of axons between test and control groups. At distal most site, recovery in both groups was too less to be commented [Figure 3]. At the intermediate proximal site ' $\mathrm{D}$ ' and the proximal most site

\begin{tabular}{|c|c|c|c|}
\hline Site & Parameter studied & Control & Test \\
\hline \multirow[t]{3}{*}{$\bar{A}$} & Remyelination ${ }^{\circledR}$ & $20 \%(5-35)$ & $25 \%(15-60)$ \\
\hline & Thick myelin\# & $0 / 5$ & $0 / 5$ \\
\hline & Axonal density ${ }^{\beta}$ & $15 \%(5-20)$ & $25 \%(20-45)$ \\
\hline \multirow[t]{3}{*}{ C } & Remyelination & $35 \%(20-35)$ & $45 \%(40-60)$ \\
\hline & Thick myelin & $0 / 5$ & $0 / 5$ \\
\hline & Axonal regeneration & $30 \%(20-40)$ & $40 \%(25-50)$ \\
\hline \multirow[t]{3}{*}{ G } & Remyelination & $40 \%(35-65)$ & $65 \%(60-75)$ \\
\hline & Thick myelin & $0 / 5$ & $0 / 5$ \\
\hline & Axonal regeneration & $40 \%(30-60)$ & $65 \%(60-70)$ \\
\hline \multirow[t]{3}{*}{ D } & Remyelination & $80 \%(75-85)$ & $85 \%(80-90)$ \\
\hline & Thick myelin & $5 / 5$ & $5 / 5$ \\
\hline & Axonal regeneration & $75 \%(75-80)$ & $80 \%(80-85)$ \\
\hline \multirow[t]{3}{*}{$F$} & Remyelination & $90 \%(85-90)$ & $90 \%(90-95)$ \\
\hline & Thick myelin & $(5 / 5)$ & $(5 / 5)$ \\
\hline & Axonal regeneration & $90 \%(85-90)$ & $90 \%(85-90)$ \\
\hline
\end{tabular}

For each site (A-F): ${ }^{@ \%}$ median (range). ${ }^{\beta}$ Mean $\%$ of axons in one field $40 x$. \#\% median (range) 
' $\mathrm{F}$, the axons in both the groups were well packed and well oriented. This can be explained on the basis that the Wallerian degeneration had extended only up to the first proximal node of Ranvier.

\section{Percentage of myelinated fibers}

In both the groups a very small percentage of myelinated fibers were seen in the distal areas ' $\mathrm{A}$ ' and ' $\mathrm{C}$ '. At the distal most site ' $\mathrm{A}$ ', test as well as control group showed thin myelinated axons and the density of myelinated axons in control ranged from $5 \%$ to $35 \%$. In the test group there were thin myelinated axons and the density ranged from $15 \%$ to $60 \%$. However, remarkable difference was observed at the repair site in two groups. All the cases with proximal sites ' $\mathrm{D}$ ' and ' $\mathrm{F}$ ' had uniformly dense myelinated fibers majority of which had uniform thickly myelinated rings [Figure 4].

\section{Schwann cell proliferation}

Schwann cell proliferation was seen in all the cases at 15 days. Extensive Schwann cell proliferation was seen in the distal stump as well as at repair site. Schwann cell proliferation started at the anastamotic site ' $G$ ' and progressed distally in both test and control groups.

\section{Degeneration and inflammatory changes}

At 15 days, degenerative changes like ballooning of axons, extensive myelin breakdown was seen at the repair site ' $G$ ' as well as at the distal areas ' $A$ ' and ' $C$ '. In all the cases focal chronic inflammatory infiltrate comprising of lymphocytes and plasma cells was seen. In addition foreign body giant cell reaction was also noticed at the repair site and in the distal stump.

\section{Longitudinal sections}

Longitudinal sections were taken at 15 days as well as 60 days with 5 control and 5 test cases in each group.

\section{Axonal regeneration}

At 15 days, although axonal regeneration was seen till the distal end, the density of axons was very less in both the groups; test cases showed marginal difference as compared to control [Figure 5]. Complete axonal regeneration was seen in test as well as in control cases till the distal most ends at the end of 60 days.

\section{Myelination}

Very few myelin rings were seen in the test as well as in control cases toward the distal end at the end of 15 days. Although the percentage of myelinated fibers was more in the test group, the difference in remyelination was not remarkable. Moreover, in both the groups only thinly myelinated fibers were seen in the distal stump. At the end of 60 days, myelination extended till the distal most ends in both the test and control groups. Although the density of myelination was good in both the groups, the myelinated fibers appeared thin in the control group [Figure 6].

\section{Growth associated protein (GAP-43) expression}

GAP-43 expression is seen as an early event after injury. Good expression of GAP-43 protein was seen at the end of 15 days and 60 days [Figure 7]. The expression however was better in the test group.

\section{Morphometric Analysis}

Morphometric analysis was performed in both the phases of 15 and 60 days. The results of morphometric analysis were as follows.

\section{At 15 days [Table 3]}

\section{Number of myelinated fibers}

At the end of 15 days although the number of myelinated fibers are more in the test group as compared to the control group at the ' $G$ ' site as well as at distal sites ' $A$ ' and ' $C$ '; however, statistically significant difference was seen only at the repair site $(P \leq 0.05)$. The mean numbers of fibers in the test group were 88 and in the control group were 47 at the repair site. Statistical analysis could not be performed for distal sites because of very less number of observations [Figure 2] (number of myelinated fibers, axons, myelin rings) although available data expressed as means is highlighted in Table 3.

\section{Axon diameter}

The mean axon diameter at the distal sites as well as the repair site was more in the test group as compared to the control group. But the difference in two groups was statistically significant at the repair site ' $G$ ' where mean axonal diameter in the test group was $2.43 \mu \mathrm{m}$ and in the control group was $1.81 \mu \mathrm{m}(P=0.008)$.

\section{Nerve fiber diameter}

Similar to axonal diameter a statistically significant difference in nerve diameter was seen at the repair site $(P=0.008)$. The mean nerve diameter at the repair site ' $G$ ' in the test group was $3.34 \mu \mathrm{m}$ and the control group was $2.96 \mu \mathrm{m}$.

\section{Myelin thickness}

A significant difference in myelin thickness was seen at the repair site $(P=0.008)$. The mean myelin thickness at the repair site ' $G$ ' in the test group was $0.81 \mu \mathrm{m}$ and the control group was $0.62 \mu \mathrm{m}$ [Figure 3].

There was no difference in any of these parameters in the proximal areas ' $\mathrm{D}$ ' and ' $\mathrm{F}$ ' which can be explained on the basis of concept of Wallerian degeneration. 


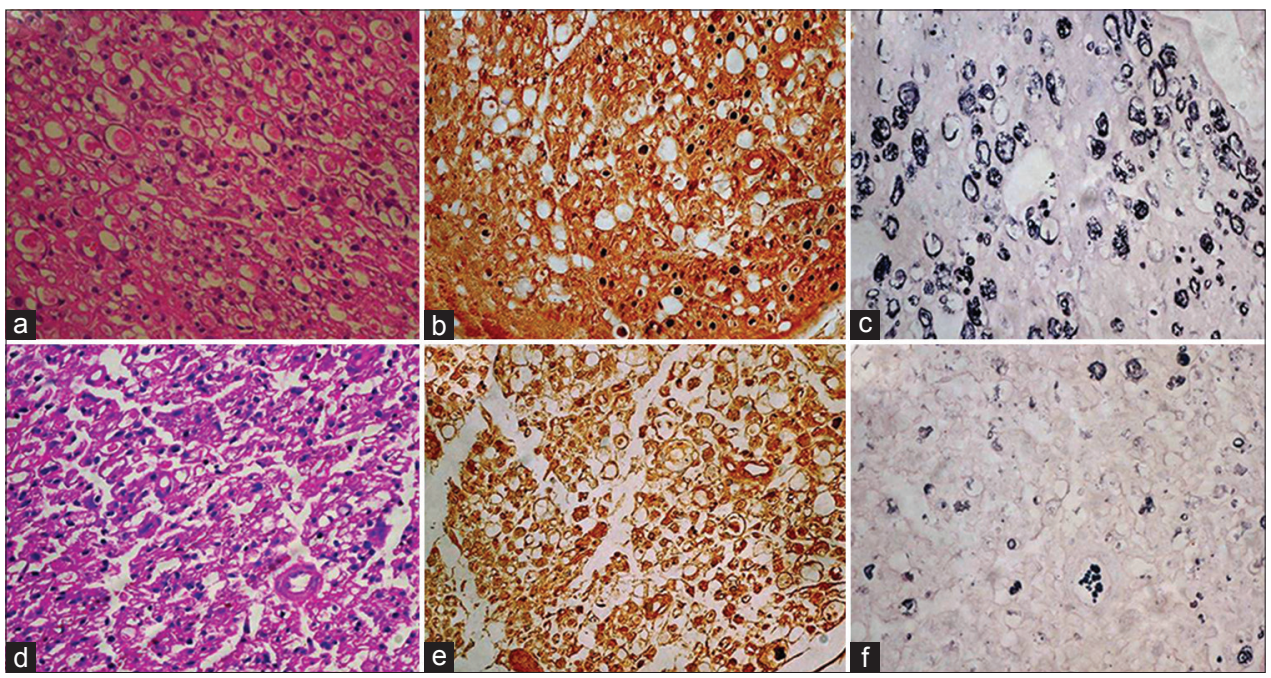

Figure 2: (a) At the distal most site at 15 days, in the test group showing Schwann cell proliferation, degenerating axons, HE $\times 400$. (b) Axons are small, haphazardly placed and sparsely distributed, NF $\times 400$. (c) Extensive breakdown of myelin rings; all are thinly myelinated, Loyez $\times 400$. (d) Extensive Schwann cell proliferation, most of the area showing degenerative changes, $\mathrm{HE} \times 400$. (e) In control cases very small axons seen with haphazard arrangement in most of areas, NF $\times 400$. (f) extensive breakdown of myelin rings and majority are thinly myelinated, Loyez $\times 400$

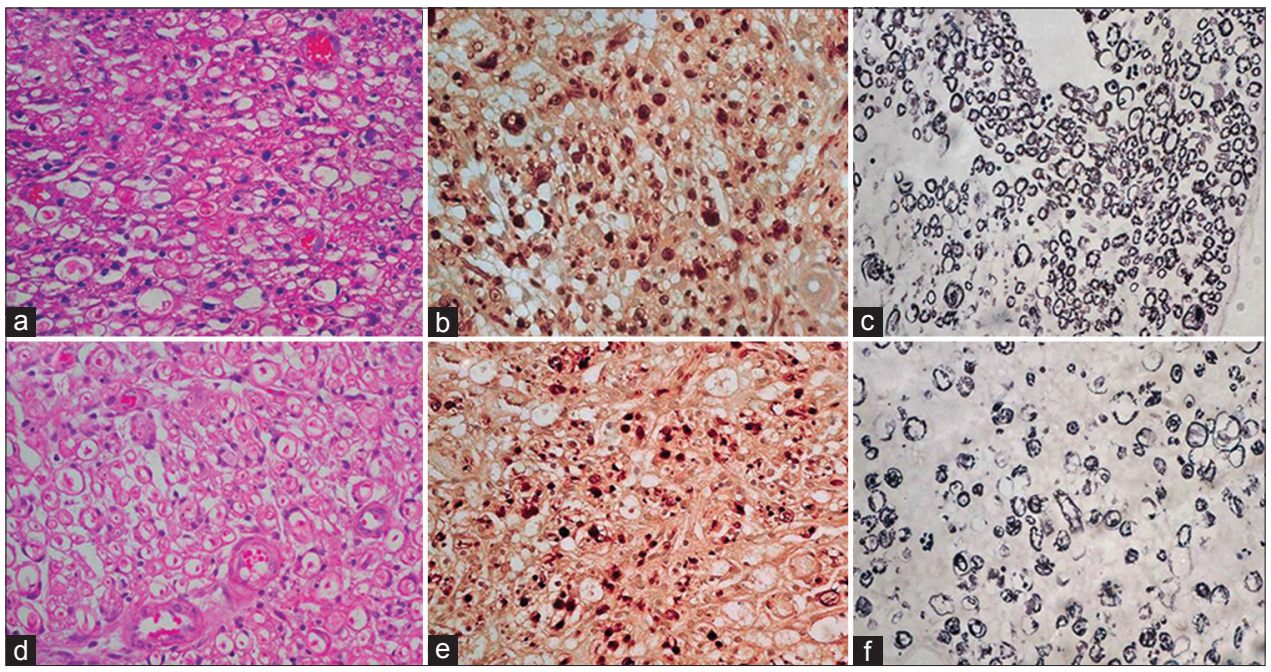

Figure 3: (a) At repair site, the test case showing mild Schwann cell proliferation with mild degenerative changes at some foci, HE $\times 400$. (b) Focal aggregates of small axons sprouts are seen, axons are small in size, NF $\times 400$. (c) Thinly myelinated, Loyez $\times 400$. (d) In control case axons sparsely placed with degenerative changes in some foci, $\mathrm{HE} \times 400$. (e) Aggregates of small axons sprouts are seen, haphazardly arranged small axons can be seen, NF $\times 400$. (f) Myelin rings are ill formed, Loyez $\times 400$

Table 3: Shows morphometric analysis at 15 days along with statistical analysis. Axon diameter, myelin thickness and nerve thickness at repair site and intermediate distal sites were significantly more in the test group than the control group at 15 days $(P<0.05)$

\begin{tabular}{|c|c|c|c|c|c|c|c|c|}
\hline \multirow[t]{2}{*}{ Region } & \multicolumn{2}{|c|}{$\begin{array}{l}\text { Mean axon } \\
\text { diameter } \\
(\mu \mathrm{m})\end{array}$} & \multicolumn{2}{|c|}{$\begin{array}{c}\text { Mean nerve } \\
\text { thickness } \\
(\mu \mathrm{m})\end{array}$} & \multicolumn{2}{|c|}{$\begin{array}{l}\text { Mean myelin } \\
\text { sheath } \\
\text { thickness }(\mu \mathrm{m})\end{array}$} & \multicolumn{2}{|c|}{$\begin{array}{c}\text { Mean } \\
\text { number } \\
\text { of fibers }\end{array}$} \\
\hline & $\mathbf{T}$ & C & $\mathbf{T}$ & C & $\mathbf{T}$ & C & $\mathbf{T}$ & C \\
\hline$A$ & 1.35 & 0.87 & 2.46 & 2.08 & 0.62 & 0.41 & 45 & 26 \\
\hline C & 1.85 & 1.16 & 2.71 & 2.39 & 0.65 & 0.52 & 60 & 33 \\
\hline G & 2.43 & 1.81 & 3.34 & 2.96 & 0.81 & 0.62 & 88 & 47 \\
\hline D & 2.21 & 2.03 & 5.08 & 4.41 & 1.42 & 1.32 & 387 & 380 \\
\hline$F$ & 2.57 & 2.43 & 5.79 & 5.23 & 1.37 & 1.36 & 398 & 392 \\
\hline
\end{tabular}

At 60 days Number of myelinated fibers

At the end of 60 days a statistically significant difference was observed in the distal areas ' $\mathrm{A}$ ' and ' $\mathrm{C}$ ' in the two groups [Table 4]. The mean number of fibers at the distal site ' $\mathrm{A}$ ' was 324 and 221 in the test and control groups, respectively $(P \leq 0.05)$, whereas at the intermediate distal site ' $C$ ' the mean number of fibers in the test group was 367 and in the control group was $243(P \leq 0.05)$.

\section{Axon diameter}

A statistically significant difference in axonal diameter was observed at the end of 60 days in the distal most 


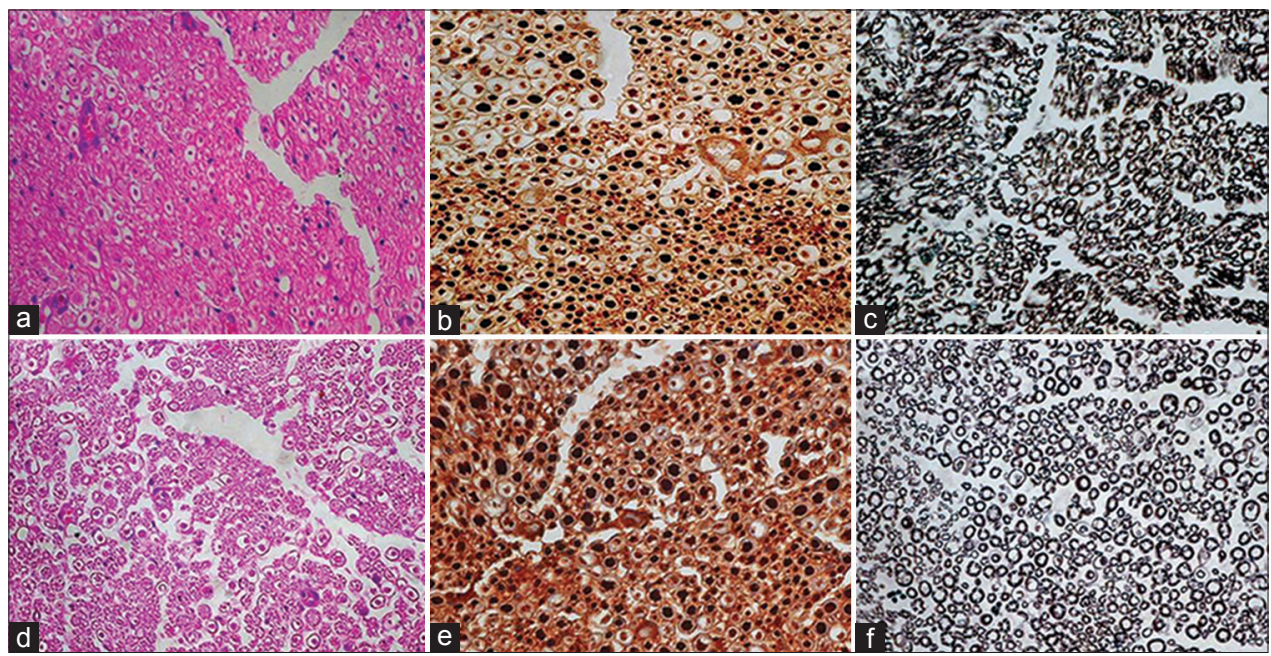

Figure 4: (a) At the proximal site, the test case showing good density of axons which are well oriented with single Schwann cells at the periphery, $\mathrm{HE} \times 400$ (b) majority of axons are large in size, NF $\times 400$ and (c) thickly myelinated, Loyez $\times 400$ (d) in case of control, axons are also in good density, $\mathrm{HE} \times 400$, (e) majority of axons are large, NF $\times 400$ and (f) thickly myelinated, Loyez $\times 400$
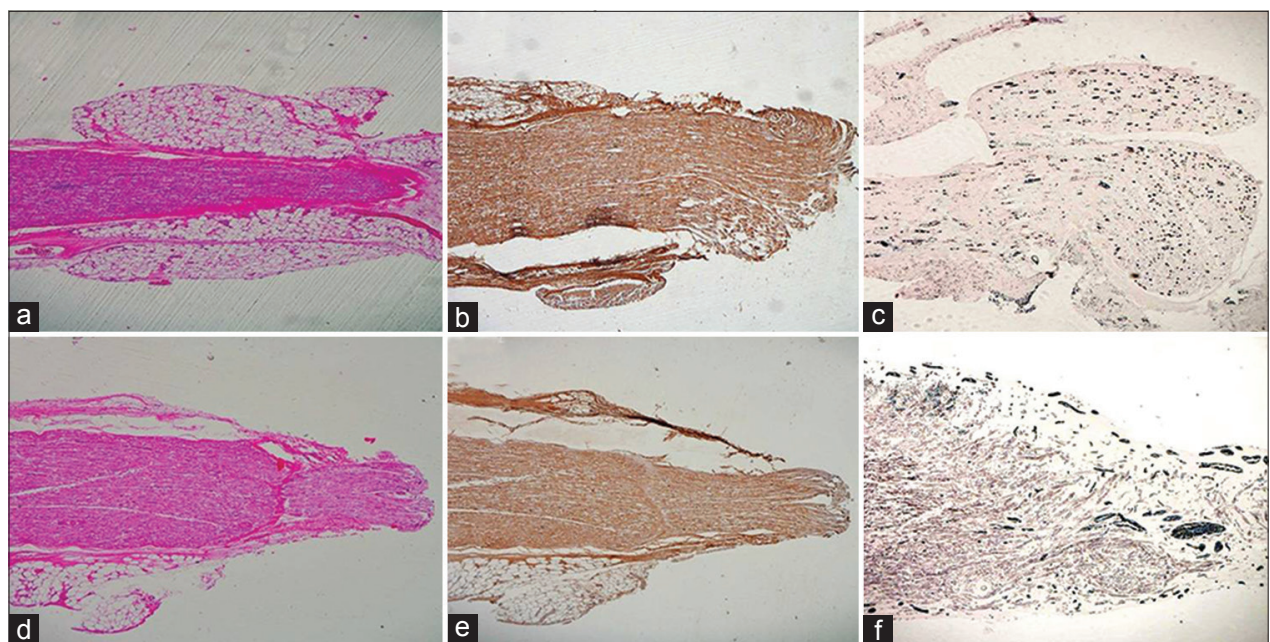

Figure 5: (a) Longitudinal sections from the test group at 15 days showing nerve regeneration in distal stump, HE $\times 40$. (b) Complete axonal regeneration till the distal most end however axons are very less, NF $\times 40$. (c) Very few myelin rings towards distal end, Loyez $\times 40$. (d) Nerve regeneration in distal end at the control site, $\mathrm{HE} \times 40$. (e) Complete axonal regeneration till the distal most site can be seen, NF $\times 40$. ( $f$ ) There are few myelin rings as compared to the test group distal end

site ' $\mathrm{A}$ ' $(P=0.001)$. The mean axonal diameter in the test group at the distal most site 'A' was $1.77 \mu \mathrm{m}$ and in the control group was $1.01 \mu \mathrm{m}$.

\section{Nerve diameter}

Statistically significant difference in nerve diameter was observed at the distal most site ' $\mathrm{A}$ ' $(P=0.03)$. The mean diameter of nerve at the distal most site ' $A$ ' in the test group was $3.46 \mu \mathrm{m}$ and in the control group was $2.49 \mu \mathrm{m}$.

\section{Myelin Thickness}

There was a significant difference in myelin thickness at the distal most site ' $\mathrm{A}$ ' $(P=0.05)$. The mean myelin thickness at the distal most site ' $\mathrm{A}$ ' in the test was $0.78 \mu \mathrm{m}$ and in the control group was $0.42 \mu \mathrm{m}$ [Figure 3].

\section{FISH assay}

The FISH assay was performed on paraffin-embedded sections. A single red signal was observed in some of the cells. Number of nucleated cells in the peripheral nerve is very less. The assay could be performed only at 15 days as Schwann cell proliferation was evident [Figure 8].

\section{Discussion}

Bone marrow mononuclear cells are easy to harvest, process and administer at repair site. In the present study, we recorded a time lag of 2 hours from harvesting to user end which included processing, isolation and standardization of concentration of cells in the solution. These cells are known to survive in biochemical milieu 


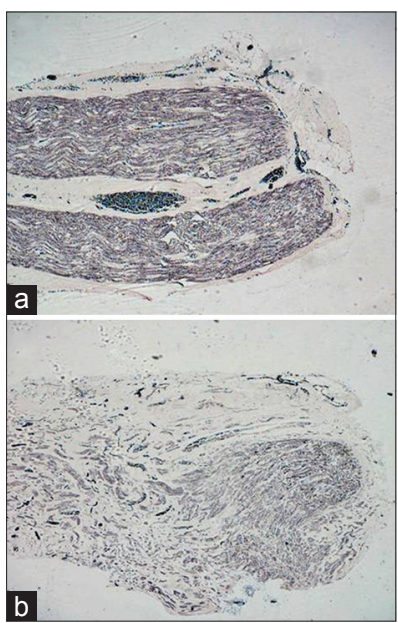

Figure 6: (a) Longitudinal sections from the test group at 60 days showing myelination extended till the distal most end and the density of myelinated fibers is good, Loyez $\times 40$. (b) In the control group, myelinated fibers extended till distal most end but the fibers are thinly myelinated, Loyez $\times 40$

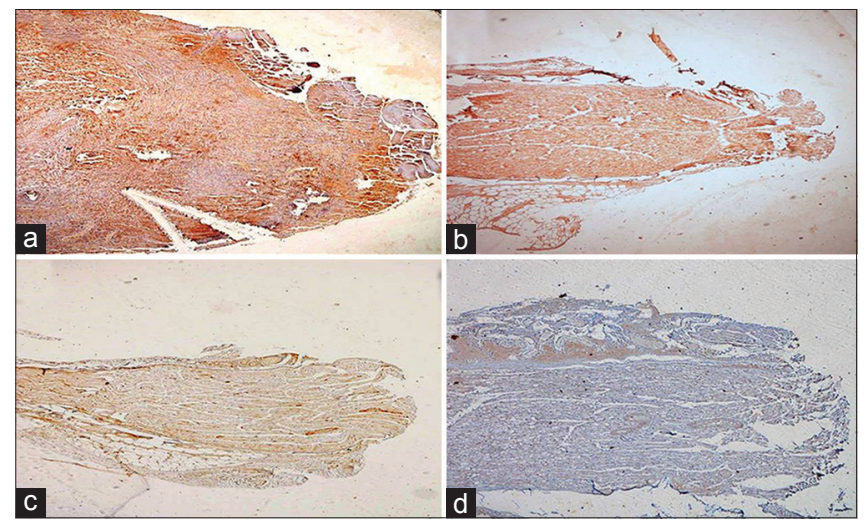

Figure 7: (a) Test case at 15 days showing good expression of GAP-43 protein, GAP- $43 \times 40$. (b) A control case at 15 days showing GAP-43 expression. (c) Very week expression of GAP-43 was seen at 2 months in test (d) as well as control group

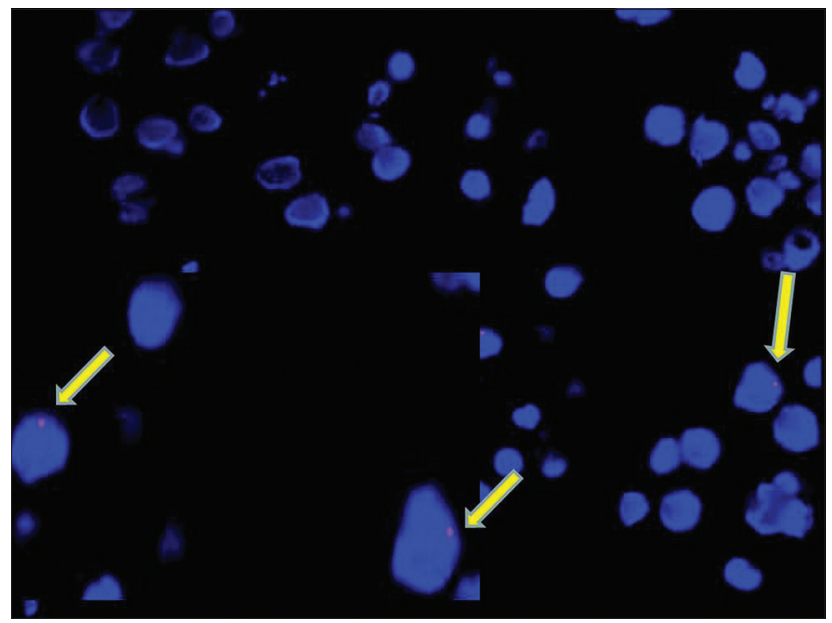

Figure 8: Photomicrograph of FISH as say for $\mathrm{Y}$ chromosome showing single red signals in occasional nucleated cells harvested from the repair site at 15 days
Table 4: Shows morphometric analysis at 60 days along with statistical analysis. Axon diameter, myelin thickness and nerve thickness at distal sites were significantly more in the test group than the control group at 60 days $(P<0.05)$

\begin{tabular}{|c|c|c|c|c|c|c|c|c|}
\hline \multirow[t]{2}{*}{ Region } & \multicolumn{2}{|c|}{$\begin{array}{c}\text { Mean axon } \\
\text { diameter } \\
(\mu \mathrm{m})\end{array}$} & \multicolumn{2}{|c|}{$\begin{array}{l}\text { Mean nerve } \\
\text { fiber thickness } \\
(\mu \mathrm{m})\end{array}$} & \multicolumn{2}{|c|}{$\begin{array}{l}\text { Mean myelin } \\
\text { sheath } \\
\text { thickness }(\mu \mathrm{m})\end{array}$} & \multicolumn{2}{|c|}{$\begin{array}{c}\text { Mean } \\
\text { number } \\
\text { of fibers }\end{array}$} \\
\hline & $\mathbf{T}$ & C & $\mathbf{T}$ & C & $\mathbf{T}$ & C & $\mathbf{T}$ & C \\
\hline$A$ & 1.77 & 1.01 & 3.46 & 2.49 & 0.78 & 0.42 & 324 & 221 \\
\hline C & 1.85 & 1.58 & 3.67 & 3.35 & 0.89 & 0.83 & 367 & 243 \\
\hline G & 2.48 & 1.79 & 3.59 & 3.33 & 1.12 & 0.80 & 397 & 255 \\
\hline D & 2.56 & 2.30 & 5.17 & 4.73 & 1.44 & 1.38 & 415 & 408 \\
\hline $\mathrm{F}$ & 2.72 & 2.64 & 5.20 & 5.17 & 1.57 & 1.56 & 421 & 417 \\
\hline
\end{tabular}

of the injury site and differentiate accordingly into a desired lineage: $:^{[16-18]}$ to Schwann cells in our case and help in myelination which in turn should improve axonal regeneration and nerve recovery. We also demonstrated the presence of the $Y$ chromosome in nucleated cells at 15 days, which are mostly Schwann cells from the repair site. Surprisingly, these cells survived without using any immunosuppression, a fact questionable in humans; however humans have enough homologues bone marrow deposits which can be harvested easily. In our study, we sutured the nerve ends and there was no gap in nerve endings, a probable reason we document a good recovery of nerve regeneration parameters in controls as well. Few authors used silicon conduits or scaffolds to fill the gap and provide mechanical support for stem cells to survive and transform into Schwann cells, which translated in good outcomes. ${ }^{[19,20]}$

Detailed morphometric analysis actually created more queries than it answered. If we look at all the nerve regeneration parameters, test rats show better axon diameter, nerve thickness and myelin rings thickness at the proximal most site which is not affected by surgical injury than in controls rats, creating a suspicion of selection bias. The only favorable point is, at no point of time and not in any single section, the difference reached a level of statistical significance. Also, at 15 days, a statistically significant difference in all nerve regeneration parameters was documented at the repair site and at 2 months a statistically significant difference is seen at intermediate and distal most sites. But interestingly, at 2 months, a statistical significance in difference at the repair site is lost in all parameters including axonal diameter. However, the conclusion that stem cells only affect myelination increasing the speed of regeneration that qualitative parameters like axon diameters is again questioned by significant difference in axon diameter at the distal site after 2 months. A fact also confirmed by analysis of longitudinal sections which showed a tightly 
packed axons in both tests and controls at the distal site at 2 months but mainly deficient myelin rings.

Axon diameter is function of proximal neuron and speed of transmission is function of myelination. We also noted statistically significant difference in diameter of myelinated axons at repair and distal sites at 15 and 60 days, respectively, an observation which supports differential effect of stem cells on variety of axons. There is a significant difference in mean number of fibers at the anastomotic site and distal sites early and late in regeneration process which highlights the importance of myelination in nerve recovery. Whether this anatomical difference translates in clinically significant recovery is not documented in the present study but there is enough literature evidence for the same. ${ }^{[8,16-18,20]}$

Extensive morphometric evaluations strictly adhering to protocols remained the main strength of study however failure to document a clinical recovery in rats and differential effects if any on motor and sensory improvement remained the main drawback of the study. This is unique study which demonstrated the utility of BMMNCs on nerve regeneration along with their ease of harvesting, processing and administration. With no ethical issues in human trials, more detailed trials on differential effect of stem cells on various axonal functions can be undertaken.

\section{Conclusion}

Transplanting $\mathrm{BM}-\mathrm{MNC}_{\mathrm{S}}$ at the site of peripheral nerve injury leads to a significantly better recovery. These differences were evident at the repair site after 15 days and distal most sites and intermediate distal site at the end of 60 days. Hence, their application at the site of injury definitely increases the rate and amount of regeneration. With practically no ethical issue regarding their isolation and application they can be easily used for clinical trials.

\section{Acknowledgement}

This research work is supported by grants from Indian Council of Medical Research, New Delhi, Government of India.

\section{References}

1. Mirsky R, Jessen KR. The neurobiology of Schwann cells. Brain Pathol 1999;9:293-311.

2. Scherer SS. The biology and pathobiology of Schwann cells. Curr Opin
Neurol 1997;10:386-97.

3. Guénard V, Kleitman N, Morrissey TK, Bunge RP, Aebischer P. Syngeneic Schwann cells derived from adult nerves seeded in semipermeable guidance channels enhance peripheral nerve regeneration. J Neurosci 1992;12:3310-20.

4. Pearse DD, Pereira FC, Marcillo AE, Bates ML, Berrocal YA, Filbin MT, et al. cAMP and Schwann cells promote axonal growth and functional recovery after spinal cord injury. Nat Med 2004;10:610-6.

5. Aquino JB, Hjerling-Leffler J, Koltzenburg M, Edlund T, Villar MJ, Ernfors P. In vitro and in vivo differentiation of boundary cap neural crest stem cells into mature Schwann cells. Exp Neurol 2006;198:438-49.

6. Heine W, Conant K, Griffin JW, Höke A. Transplanted neural stem cells promote axonal regeneration through chronically denervated peripheral nerves. Exp Neurol 2004;189:231-40.

7. Tohill M, Mantovani C, Wiberg M, Terenghi G. Rat bone marrow mesenchymal stem cells express glial markers and stimulate nerve regeneration. Neurosci Lett 2004;362:200-3.

8. Zhang P, He X, Liu K, Zhao F, Fu Z, Zhang D, et al. Bone marrow stromal cells differentiated into functional Schwann cells in injured rats sciatic nerve. Artif Cells Blood Substit Immobil Biotechnol 2004;32:509-18.

9. Chen X, Wang XD, Chen G, Lin WW, Yao J, Gu XS. Study of in vivo differentiation of rat bone marrow stromal cells into schwann cell-like cells. Microsurgery 2006;26:111-5.

10. Dezawa M, Takahashi I, Esaki M, Takano M, Sawada H. Sciatic nerve regeneration in rats induced by transplantation of in vitro differentiated bone-marrow stromal cells. Eur J Neurosci 2001;14:1771-6.

11. Cuevas P, Carceller F, Garcia-Gómez I, Yan M, Dujovny M. Bone marrow stromal cell implantation for peripheral nerve repair. Neurol Res 2004;26:230-2.

12. Mimura T, Dezawa M, Kanno H, Sawada H, Yamamoto I. Peripheral nerve regeneration by transplantation of bone marrow stromal cell-derived Schwann cells in adult rats. J Neurosurg 2004;101:806-12.

13. Goel RK, Suri V, Suri A, Sarkar C, Mohanty S, Sharma MC, et al. Effect of bone marrow-derived mononuclear cells on nerve regeneration in the transection model of the rat sciatic nerve. J Clin Neurosci 2009;16:1211-7.

14. Suri A, Mehta VS, Sarkar C. Microneural anastomosis with fibrin glue: An experimental study. Neurol India 2002;50:23-6.

15. Berthold F. Isolation of human monocytes by Ficoll density gradient centrifugation. Blut 1981;43:367-71.

16. Woodbury D, Schwarz EJ, Prockop DJ, Black IB. Adult rat and human bone marrow stromal cells differentiate into neurons. J Neurosci Res 2000;61:364-70.

17. Deng W, Obrocka M, Fischer I, Prockop DJ. In vitro differentiation of human marrow stromal cells into early progenitors of neural cells by conditions that increase intracellular cyclic AMP. Biochem Biophys Res Commun 2001;282:148-52.

18. Sanchez-Ramos J, Song S, Cardozo-Pelaez F, Hazzi C, Stedeford T, Willing A, et al. Adult bone marrow stromal cells differentiate into neural cells in vitro. Exp Neurol 2000;164:247-56.

19. Hu J, Zhu QT, Liu XL, Xu YB, Zhu JK. Repair of extended peripheral nerve lesions in rhesus monkeys using acellular allogenic nerve grafts implanted with autologous mesenchymal stem cells. Exp Neurol 2007;204:658-66.

20. Braga-Silva J, Gehlen D, Padoin AV, Machado DC, Garicochea B, Costa da Costa J. Can local supply of bone marrow mononuclear cells improve the outcome from late tubular repair of human median and ulnar nerves? J Hand Surg Eur Vol 2008;33:488-93.

How to cite this article: Kurwale NS, Suri V, Srivastava A, Suri A, Mohanti S, Yadav P, et al. Role of bone marrow derived pluripotent stem cells in peripheral nerve repair in adult rats: A morphometric evaluation. J Neurosci Rural Pract 2015;6:152-9.

Source of Support: The funds for this project were provided by Indian council of Medical Research (ICMR) New Delhi-110029. Conflict of Interest: None declared. 